\title{
EVALUASI PENGGUNA PADA PERPUSTAKAAN DIGITAL UNIVERSITAS AIRLANGGA (UNAIR)
}

\section{USER EVALUATION ON THE DIGITAL LIBRARY OF AIRLANGGA UNIVERSITY}

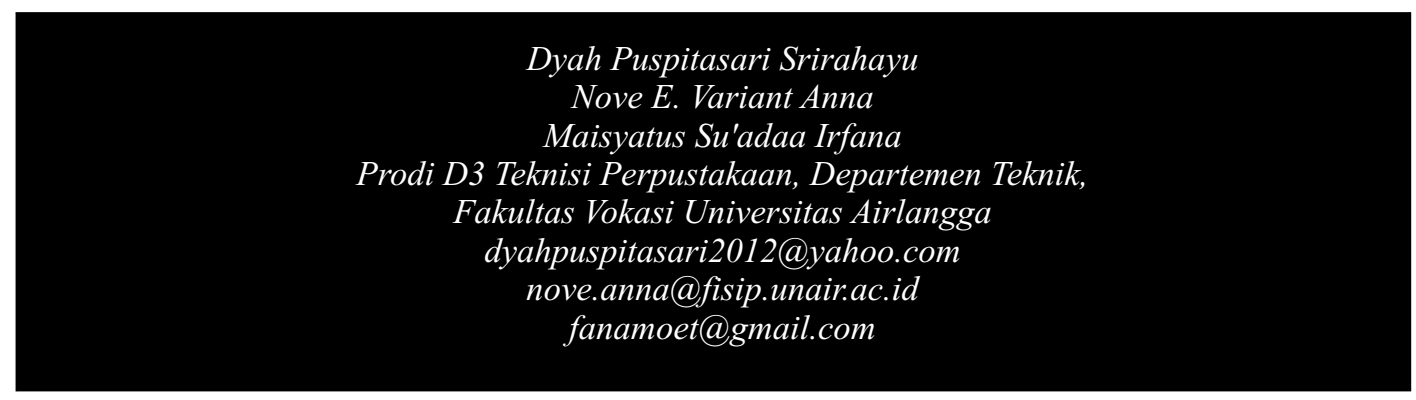

Abstrak. Penelitian ini bertujuan untuk mengevaluasi website perpustakaan digital UNAIR yang beralamat di www.lib.unair.ac.id melalui user evaluation teknik. Adapun komponen dari digital library UNAIR yang akan di evaluasi dengan menggunakan teori usefulnees digital library yang terdiri dari enam dimensi yakni format penyajian informasi, coverage (cakupan) informasi, relevance (kesesuain informasi yang disajikan), reliable (bisa dipertanggungjawabkan), dan level (tingkat aksesibilitas informasi). Penelitian ini menggunakan sampel sebanyak 50 responden, dengan teknik purposive sampling,

dengan kriteria sebagai berikut: (1) civitas akademia UNAIR, (2) pernah mengakses digital library website minimal 1 kali dalam sebulan. Dari hasil penelitian dapat disimpulkan bahwa usefullness dari website perpustakaan UNAIR

(lib.unair.ac.id) termasuk dalam kategori TINGGI dengan nilai 99.9 dan yang paling tinggi nilainya adalah format (misalnya .pdf, .jpg lain .doc) dengan point 89.5 dan yang paling rendah adalah cakupan (yaitu ketepatan waktu dalam hal up-

Kata Kunci: Evaluasi Pengguna, Perpustakaan Digital

Abstract. This study aimed to evaluate the digital library website of Airlangga University (www.lib.unair.ac.id) through user evaluation technique. The components of the digital library that will be evaluated using usefulness digital library theory consisted of six dimensions namely information presentation format,

information coverage, information relevance, information reliability, and information accessibility level. This study used a sample of 50 respondents selected by purposive sampling technique and with the following criteria: (1) Academic community of UNAIR, (2) Have accessed digital library website at least once a month. The results of the study suggested that the usefulness of UNAIR library website is considered in HIGH category with the score of 99.9. The highest score is for the format (e.g. pdf, jpg, doc) with 89.5 points and the lowest is the coverage

(i.e. punctuality in terms of updating or diachronic completeness) with 109.6

Keywords: User Evaluation, Digital Library 


\section{A. Pendahuluan}

erpustakaan adalah sebuah
organisasi yang bergerak
dibidang jasa. Seperti organisasi lainnya sebuah perpustakaan akan terus berkembang mengikuti perkembangan jaman. Hal ini sesuai dengan dalil kelima Ranganathan (dalam sulistyo-basuki, 1991) bahwa "The library is a growing organism". Berkembangnya sebuah perpustakaan tidak akan pernah lepas dari pengaruh kebutuhan pengguna pada saat ini. Pengguna perpustakaan pada saat ini lebih banyak menghabiskan waktu di depan komputer, laptop atau handphone dalam mencari informasi. Melihat perubahan tersebut, banyak perpustakaan yang membangun perpustakaan digital dan bisa diakses secara online.

Perpustakaan digital di indonesia mulai dirintis pada tahun 1998 seperti yang diungkap oleh Surachman (2011) bahwa cikal-bakal jaringan dan kerjasama antar perpustakaan di Indonesia dalam rangka mewujudkan jaringan perpustakaan digital telah dimulai sejak tahun 1998 yakni kerjasama antara Universitas Petra sebagai inisiator bersama delapan institusi yang membentuk jaringan bernama Indonesian Christian Libraries-Virtual Library (InCU-VL). Sebenarnya inisiatif lebih awal telah dimulai oleh sebuah kelompok peneliti di bidang manajemen pengetahuan di Universitas Teknologi
Bandung (ITB) dengan gagasan Indonesia Digital Library Network (IDLN) yang diikuti dengan peluncuran aplikasi perpustakaan digital yang dikenal dengan Ganesha Digital Library (GDL). Selang belasan tahun kemudian, bermunculan berbagai inisiatif dan jaringan perpustakaan digital yang melibatkan pihak pemerintah, swasta, serta komunitas masyarakat.

Di Universitas Airlangga (UNAIR) juga ikut mengembangkan perpustakaan digital dengan menggunakan aplikasi perpustakaan digital "GDL" yang dibuat oleh ITB dan mulai dirintis pada tahun 2002. Koleksi yang ada dalam adln.lib.uanir.ac.id sekarang berjumlah 423.025 judul dengan berbagai macam koleksi. Namun masih terbatas pada hasil karya civitas akademika UNAIR seperti disertasi, tesis, skripsi dan tugas akhir. Digital library yang dibahas dalam paper ini adalah perpustakaan digital UNAIR yang beralamat di www.lib.unair.ac.id. Pemilihan perpustakaan digital ini karena selain melayankan koleksi umum melalui OPAC dan berbagai layanan informasi lainnya.

Evaluasi diperlukan dalam semua kegiatan yang akan dan pernah dilakukan. Evaluasi berguna untuk melihat sampai sejauh mana hasil yang telah dicapai untuk sebuah program atau kegiatan yang telah dilaksanakan. Hasil evaluasi tersebut nantinya akan digunakan untuk memberikan masukan untuk perbaikan 
dari program tersebug. Hal ini juga berlaku untuk implementasi perpustakaan digital yang telah dilakukan oleh UNAIR. Evaluasi yang dilakukan dalam penelitian ini lebih kepada kegunaan (usefulness) perpustakaan digital dari pengguna perpustakaan digital itu sendiri karena apa yang telah dibuat oleh perpustakaan UNAIR dalam mengembangkan perpustakaan digital tidak akan bermanfaat jika perpustakaan digital tersebut tidak digunakan.

Paper ini ingin menjawab beberapa pertanyaan antara lain (1) Bagaimana evaluasi pengguna terhadap perpustakaan digital UNAIR berdasarkan konsep usefulness digital library?, (2) Dimensi manakah yang paling tinggi dalam hasil evaluasi perpustakaan digital Universitas airlangga?

\section{B. Hasil dan Pembahasan}

\section{Perpustakaan Digital}

Perpustakaan digital merupakan perkembangan dari perpustakaan yang telah ada. Konsep perpustakaan digital sendiri berbeda-beda tergantung dari sudut pandang lembaga yang mendefinisikannya, antara lain adalah Digital Library Federation di Amerika Serikat memberikan definisi perpustakaan digital sebagai organisasiorganisasi yang menyediakan sumbersumber informasi, termasuk staf dengan keahlian khusus untuk menyeleksi, menyusun, menginterpretasikan, membe- rikan akses intelektual, mendistribusikan, melestarikan, dan menjamin keberadaan koleksi karya-karya digital sepanjang waktu sehingga koleksi tersebut dapat digunakan oleh komunitas masyarakat tertentu atau masyarakat terpilih secara ekonomis dan mudah (Purtini, 2005). Berdasarkan International Conference of Digital Library 2004, konsep perpustakaan digital adalah sebagai perpustakaan elektronik yang informasinya didapat, disimpan, dan diperoleh kembali melalui format digital. Perpustakaan digital merupakan kelompok workstations yang saling berkaitan dan terhubung dengan jaringan (networks) berkecepatan tinggi. Pustakawan menghadapi tantangan yang lebih besar dalam mendapatkan, menyimpan, memformat, menelusuri atau mendapatkan kembali, dan memproduksi informasi non teks. Sistem informasi modern kini dapat menyajikan informasi. Menurut Pendit (2008) perpustakaan digital adalah sebagai suatu persekutuan berbagai organisasi yang menjalankan peran kepustakawanan: memilih, mengatur, menawarkan akses, memahami, menyebarkan, menjaga integritas, dan memastikan keutuhan karya.

Perubahan paradigma dari perpustakaan tradisional ke perpustakaan digital telah terjadi pada akhir tahun 1999 seperti yang diungkapkan oleh Griffin (1999) bahwa pada tahun terakhir ini telah 
terjadi peledakan pertumbuhan ketertarikan dalam perkembangan dan pemakaian perpustakaan digital. Beberapa faktor penunjangnya adalah (1) Telah tersedianya teknologi komputasi dan komunikasi yang memungkinkan dilakukannya penciptaan, pengumpulan dan manipulasi informasi.(2) Infrastruktur jaringan internasional untuk mendukung sambungan dan kemampuan pengoprasian bagi pengguna. (3) Informasi online mulai berkembang. (4) Kerangka akses internet umum telah muncul.

\section{Evaluasiperpustakaan digital}

Evaluasi didefinisikan sebagai proses sistematis untuk menentukan kegunaan, manfaat, nilai dan harga dari sesuatu. Dalam perpustakaan digital evaluasi berarti proses untuk menentukan apakah maksud dan tujuan dari perpustakaan digital dapat tercapai. Dalam proses evaluasi ada beberapa hal yang perlu dikaji yaitu (1) apa maksud dan tujuan evaluasi, (2) Apa yang akan dievaluasi, (3) bagaimana cara mengevaluasinya, dan (4) kapan waktu yang tepat untuk evaluasi (Rufaidah, 2009). Dalam mengevaluasi perpustakaan digital metode yang digunakan lebih kompleks. Ada bermacam teknik mengevaluasi perpustakaan digital, tergantung dari tipe perpustakaan dan maksud serta tujuan evaluasi. Ada yang mengevaluasi user interfacenya, usability dan lain sebagainya. Teknik yang biasanya digunakan adalah transaction log analysis, metode survei, interview dan fokus grup dan observasi.

Dalam mengevaluasi sebuah perpustakaan digital, user interface saja tidak cukup untuk membuat pengguna memanfaatkan sebuah media informasi, namun pengguna akan lebih tertarik pada isi atau konten informasi tersebut. Untuk mengevaluasi konten atau isi informasi banyak cara yang digunakan dengan menggunakan beberapa metode usability seperti heuristic evaluations, user acceptance testing namun jarang sekali metode usefulness digunakan dalam mengevaluasi perpustakaan digital dan layanan informasi. Seperti dengan menggunakan konsep usability, namun selain usability adalagi metode evaluasi yang digunakan yaitu usefulness. Konsep evaluasi dengan Usefulness hampir sama dengan evaluasi usability, usefulness informasi dapat dievaluasi sebelum, selama dan implementasi perpustakaan digital untuk melihat hasil yang telah diperoleh dan juga untuk menghapus datadata yang ada karena mungkin pengguna menganggap informasi tersebut tidak berguna lagi.

Kerangka usefulness yang diungkapkan oleh Hugi \& Schneider (2013) ini menyelidiki hubungan antara tiga komponen utama: sistem, pengguna, dan konten yang disediakan, sedangkan hubungan antara pengguna dan konten 
mendefinisikan sumbu evaluasi usefulness. Sumbu ini didasari oleh lima atribut atau variabel evaluasi, seperti a) relevansi (yaitu kesesuaian informasi yang ditemukan sesuai dengan kebutuhannya); b) format (misalnya .pdf, .jpg lain .doc); c) kehandalan (yaitu pentingnya dan kepercayaan diberikan kepada hasil pencarian dalam korespondensi untuk informasi perlu atau diberikan tugas; d) tingkat (seperti meta data, abstrak, teks lengkap dll) dan e) cakupan (yaitu ketepatan waktu dalam hal up-to-date atau kelengkapan diakronis). Singkatnya, atribut dan variabel setara mereka menggambarkan interaksi antara pengguna dan konten sebagai akibat dari literasi informasi penggunaanya, kebutuhan aktual dan preferensi, isi di pembuangan dan sesuai fungsi sistem untuk presentasi, transmisi dan penyimpanan.

\section{Metodologi Penelitian}

Penelitian ini menggunakan pendekatan kuantitatif dengan metode deskriptif karena tujuan dari penelitian ini adalah untuk memberi gambaran tentang perpustakaan digital UNAIR dari sudut pandang pengguna. Lokasi penelitian adalah perpustakaan UNAIR, populasi yang menjadi obyek penelitian yaitu seluruh pengguna perpustakaan UNAIR yang sudah pernah mengakses perpustakaan digital UNAIR (lib.unair.ac.id). Kriteria penentuan sam- pel adalah minimal 1 kali mengguna-kan perpustakaan digital (mengakses informasi) dalam kurun waktu 1 bulan terakhir. Jumlah sampel yang diambil sejumlah 50 responden.

\section{Temuan dan Analisis Data}

Data dihasilkan dari survey responden yang pernah mengakses website perpustakaan digital UNAIR. Sebagian besar responden dijaring di perpustakaan UNAIR Kampus B, dengan asumsi bahwa perpustakaan UNAIR Kampus B adalah perpustakaan pusat dan terbesar, selain itu perpustakaan juga menjadi meeting point bagi civitas akademika. Penyebaran kuesioner dilakukan dalam kurun waktu 3 minggu. Berikut deskripsi temuan data yang telah dihasilkan.

Berdasarkan hasil pengolahan data diperoleh data responden sebagai berikut, umur responden yang mengakses website perpustakaan digital UNAIR didominasi oleh responden dengan usia 18-20 tahun sebanyak $72 \%$, dan sisanya umur 21-23 tahun sebanyak 28\%. Pengunjung perpustakaan didominasi oleh mahasiswa terutama mahasiswa D3 dan S1, yakni mahasiswa dengan usia 1823 tahun dan lahir pada range tahun 19921997, menurut Horovitz, 2012 generasi yang lahir pada range tahun tersebut masuk kategori Net Gen, digital native, atau Genration Z. Dimana generasi ini sangat dekat sekali dengan pemanfaatan teknologi.Memang belum ada istilah yang 
tepat untuk menggambarkan generasi setelah era generasi millennium dan generation Y. Jika dikaitkan dengan aksesibilitas responden dengan kategori generation $Z$ dengan website perpustakaan digital UNAIR, diasumsikan bahwa mereka tidak mengalami kesulitan yang berarti ketika mengakses internet, karena internet sudah menjadi bagian hidup generation $\mathrm{Z}$.

M a y oritas responden menghabiskan 2-9 jam/hari untuk berinternet sebanyak 64\%. Selanjutnya 10-17 jam/hari sebanyak 28\%, dan 18-25 jam/hari sebanyak 8\%. Jika dikaitkan dengan data sebelumnya, bahwa responden adalah termasuk generasi $\mathrm{Z}$ atau digital native atau new silent generation dimana sebagian besar waktu mereka dihabiskan dengan memainkan gadget yang tersambung ke internet. Waktu yang dihabiskan untuk mengakses internet cukup panjang sehingga m e mungkinkan us er untuk mengembangkan kemampuan mereka dalam memanfaatkan berbagai sumber informasi online, mengeksplorasi fiturfitur baru di internet.Termasuk jika responden adalah mahasiswa, yang mana salah satu kewajiban mereka adalah mengakses sumber informasi ilmiah melalui perpustakaan, baik online maupun off-line.

Pengguna paling banyak menghabiskan waktunya berinternet untuk membuka sosial media yakni seba- nyak 38\%, aktivitas selanjutnya adalah gabungan antara mengakses informasi dari website, membuka sosial media dan email sebanyak (26\%). Untuk jawaban mencari informasi melalui website serta sosial media sebanyak (10\%), jawaban mencari informasi melalui website sebanyak (14\%) dan yang paling sedikit menjawab mencari informasi melalui website serta email sebanyak 1 responden (2\%). Generasi Z sangat ketakutan jika mereka merasa tertinggal (ketinggalan informasi), sehingga mereka rata-rata aktif di sosial media untuk tetap up to date (Peterson, 2014).Generasi ini juga sangat mandiri dan individual, terutama dalam mendapatkan informasi, sehingga bisa dijelaskan bahwa aktivitas mereka di dunia maya merupakan kebutuhan utama.

Pengguna mengakses internet di rumah sebanyak 19 responden (38\%), selanjutnya adalah responden dengan jawaban dirumah dan kampus sebanyak 13 responden (26\%). Responden dengan jawaban dirumah, kampus serta warnet sebanyak 12 responden (24\%) dan jawaban yang palig sedikit adalah dikampus sebanyak 6 responden (12\%). Mahasiswa banyak menghabiskan waktu di kampus, namun tidak banyak mahasiswa yang mengakases internet melalui wifi kampus. Perpustakaan Unair sebetulnya menyediakan ruangan khusus yang menyediakan free wifi bagi mahasiswa dan ruang komputer yang tersambung ke internet. Namun dari hasil 
probing menyebutkan bahwa wifi dan koneksi internet di kampus lambat sehingga kurang nyaman jika dibuat untuk menjelajah internet. Menurut hasil penelitian Nielsen, 2010, menjelaskan bahwa pengguna tidak menyukai koneksi internet lambat, dan jika tidak berhasil membuka halaman website bukan berarti ukuran gambar atau animasi yang berat tetapi itu adalah masalah koneksi.

Sebagian besar user memilih untuk mengakses internet di rumah, saat ini banyak pengguna yang berlangganan internet baik mobile internet maupun di wifi. Saat ini banyak penyedia internet yang menawarkan harga berlangganan internet dengan harga bersaing. Kecepatan yang ditawarkan juga cukup besar misalnya 3 Mbps ke atas. Selain itu teknologi smart phone dan mobile internet juga sudah menjamur sehingga memudahkan pengguna ketika mengakses internet. Sebagian besar responden mengakses website perpustakaan sebanyak 1-3 kali yakni (94\%), jawaban 4-7 kali sebanyak (4\%) dan jawaban 5 kali sebanyak (1\%). Dilihat jumlah akses ke website perpustakaan digital UNAIR yang cukup sedikit memberikan gambaran bahwa perpustakaan UNAIR belum menjadi sumber informasi utama bagi civitas akademika. Ada beberapa hal yang bisa dijadikan alasan, pertama adalah tidak semua informasi ilmiah diunggah dan bisa di download oleh pengguna perpustakaan secara online. Misalnya sumber informasi dari database jurnal yang hanya bisa diakses secara full text hanya dapat dilakukan di perpustakaan UNAIR, demikian juga dengan koleksi institutional repository.

1. Dimensi format dalam evaluasi digital library terdiri dari informasi yang disajikan dalam website digital library mudah dipahami dan layout website mudah dioperasikan. Responden menyatakan bahwa bahasa dalam website perpustakaan digital UNAIR mudah dipahami sebanyak $96 \%$. Hanya 4\% yang menyatakan bahwa bahasa sulit dipahami. Dalam website perpustakaan Unair bahasa yang digunakan cukup baku sehingga mudah dipahami dan tidak bermakna ganda. Bahasa dalam menu-menu di website juga mudah dipahami oleh pengguna. Layout website perpustakaan UNAIR memudahkan pengguna untuk menelusur informasi pada website tersebut. Sebagian besar setuju bahwa layout website perpustakaan mudah untuk dinavigasikan, dan $24 \%$ menyatakan bahwa website tidak mudah dinavigasikan. Termasuk dalam layout desain website antara lain penataan menu-menu dalam website yang mudah untuk 
ditelusur dan struktur informasi jelas.

2. Dimensi Coverage, dimensi ini termasuk cakupan informasi pada website, kedalaman informasi yang disajikan, kebaruan informasi (uptodate-ness), dan kelengkapan informasi. Cakupan informasi pada website UNAIR luas, yakni mencakup berbagai macam informasi mulai dari informasi umum terkait perpustakaan, informasi kegiatan yang diselenggarakan oleh perpustakaan, informasi koleksi baik cetak dan online, serta layanan di perpustakaan. Jawaban terbanyak adalah setuju bahwa informasi pada website perpustakaan UNAIR luas dan banyak, sebanyak (66\%). Jawaban tidak setuju sebanyak (24\%) dan jawaban sangat setuju sebanyak $(10 \%)$.

Informasi yang tersedia pada website UNAIR disajikan secara mendalam. Jawaban terbanyak adalah setuju sebanyak (58\%). Jawaban tidak setuju sebanyak (17\%) dan jawaban sangat setuju sebanyak (8\%). Informasi pada website perpustakaan digital UNAIR update, mayoritas menyatakan setuju sebanyak (64\%). Jawaban tidak setuju sebanyak (24\%) dan jawaban sangat setuju sebanyak (12\%). Website UNAIR selalu update secara reguler, jawaban terbanyak adalah setuju sebanyak (66\%), jawaban tidak setuju sebanyak (22\%). Jawaban sangat setuju sebanyak (10\%) dan jawaban sangat tidak setuju sebanyak $(2 \%)$.

4. Dimensi Relevance, dalam dimensi ini termasuk kesesuaian informasi dengan kebutuhan informasi pengguna, dan apakah website digital library menarik. Pendapat pengguna terhadap kelengkapan informasi dalam website perpustakaan UNAIR. Dari hasil olah data di dapat bahwa pengguna menyatakan sangat setuju tentang kelengkapan informasai website perpustakaan unair adalah $10 \%$, sedangkan yang setuju 52\% dan yang tidak setuju sebanyak $38 \%$.Pendapat pengguna terhadap informasi yang ada di website perpustakaan UNAIR menarik. Dari hasil olah data di dapat bahwa pengguna menyatakan sangat setuju sebanyak $14 \%$, sedangkan yang setuju $24 \%$ dan yang tidak setuju sebanyak $19 \%$.

\section{Dimensi Reliability}

Pendapat pengguna terhadap informasi yang ada di website perpustakaan UNAIR dapat di- 
Percaya. Dari hasil olah data di dapat bahwa pengguna menyatakan sangat setuju sebanyak $30 \%$, sedangkan yang setuju $64 \%$ dan yang tidak setuju sebanyak $6 \%$. Pendapat pengguna terhadap informasi yang ada di website perpustakaan UNAIR dapat diidentifikasi dengan jelas. Dari hasil olah data di dapat bahwa pengguna menyatakan sangat setuju sebanyak $18 \%$, sedangkan yang setuju $72 \%$ dan yang tidak setuju sebanyak 10\%. Pendapat pengguna terhadap informasi yang ada di website perpustakaan UNAIR terpercaya. Dari hasil olah data di dapat bahwa pengguna menyatakan sangat setuju sebanyak $28 \%$, sedangkan yang setuju $66 \%$ dan yang tidak setuju sebanyak $6 \%$.

\section{Dimensi Level}

Pendapat pengguna tentang apakah mereka mengakses informasi dalam website. Dari hasil olah data di dapat bahwa pengguna menyatakan sangat setuju sebanyak $10 \%$, sedangkan yang setuju $68 \%$ dan yang tidak setuju sebanyak 2\%. Pendapat pengguna tentang Informasi dalam website perpustakaan UNAIR dapat diakses dimana saja. Dari hasil olah data di dapat bahwa pengguna menyata- kan sangat setuju sebanyak 30\%, sedangkan yang setuju 64\% dan yang tidak setuju sebanyak 6\%. Pendapat pengguna tentang Informasi dalam website perpustakaan UNAIR dapat diakses oleh siapa saja. Dari hasil olah data didapat bahwa pengguna menyatakan sangat setuju sebanyak $22 \%$, sedangkan yang setuju $54 \%$ dan yang tidak setuju sebanyak $24 \%$.

\section{Diskusi dan Analisis}

Untuk mengetahui analisa website perpustakaan UNAIR maka dalam penelitian ini, menggunakan metode penjumlahan dari hasil kuisoner yang akan dibagi dalam tingkatan tinggi sedang rendah. Dalam penelitian ini kuisioner terbagi dalam 19 variabel dengan empat (4) skala likert yaitu sangat setuju (SS), setuju (S), tidak setuju (TS), sangat tidak setuju (STS) dengan nilai 1 untuk SS, 2 untuk S, 3 untuk TS dan 4 untuk STS, sehingga nilai terendah adalah $1 \times 50=50$ dan nilai tertinggi adalah $4 \times 50=200$. Dan akan dibagi dalan tiga (3) kategori yaitu tinggi sedang rendah.

$$
200-50=150: 3=50
$$

Jadi range adalah 50 sehingga didapat range sebaga berikut:

\begin{tabular}{|l|l|}
\hline \multicolumn{1}{|c|}{ Range } & \multicolumn{1}{c|}{ Kategori } \\
\hline $50-99$ & Tinggi \\
\hline $100-149$ & Sedang \\
\hline $150-200$ & Rendah \\
\hline
\end{tabular}


Tabel 1. Frekuensi user

\begin{tabular}{|l|l|r|r|r|r|r|r|r|r|r|r|r|r|r|r|r|}
\hline \multicolumn{2}{|c|}{ Kuisoner } & $\mathbf{5}$ & $\mathbf{6}$ & $\mathbf{7}$ & $\mathbf{8}$ & $\mathbf{9}$ & $\mathbf{1 0}$ & $\mathbf{1 1}$ & $\mathbf{1 2}$ & $\mathbf{1 3}$ & $\mathbf{1 4}$ & $\mathbf{1 5}$ & $\mathbf{1 6}$ & $\mathbf{1 7}$ & $\mathbf{1 8}$ & $\mathbf{1 9}$ \\
\hline Jml & Valid & 50 & 50 & 50 & 50 & 50 & 50 & 50 & 50 & 50 & 50 & 50 & 50 & 50 & 50 & 50 \\
Responden & Missing & 0 & 0 & 0 & 0 & 0 & 0 & 0 & 0 & 0 & 0 & 0 & 0 & 0 & 0 & 0 \\
Mean & 1,66 & 1,92 & 2,14 & 2,26 & 2,12 & 2,16 & 2,28 & 2,12 & 2,24 & 1,76 & 1,92 & 1,78 & 2,24 & 1,76 & 2,02 \\
Median & 2,00 & 2,00 & 2,00 & 2,00 & 2,00 & 2,00 & 2,00 & 2,00 & 2,00 & 2,00 & 2,00 & 2,00 & 2,00 & 2,00 & 2,00 \\
Mode & 2 & 2 & 2 & 2 & 2 & 2 & 2 & 2 & 2 & 2 & 2 & 2 & 2 & 2 \\
\hline Sum & $\mathbf{8 3}$ & $\mathbf{9 6}$ & $\mathbf{1 0 7}$ & $\mathbf{1 1 3}$ & $\mathbf{1 0 6}$ & $\mathbf{1 0 8}$ & $\mathbf{1 1 4}$ & $\mathbf{1 0 6}$ & $\mathbf{1 1 2}$ & $\mathbf{8 8}$ & $\mathbf{9 6}$ & $\mathbf{8 9}$ & $\mathbf{1 1 2}$ & $\mathbf{8 8}$ & $\mathbf{1 0 1}$ \\
\hline
\end{tabular}

Dari tabel 1 dapat dilihat bahwa website perpustakaan UNAIR jika dilihat bahwa:

1) Informasi dalam website perpustakaan UNAIR lengkap termasuk dalam kategori sedang dengan nilai 114 (poin 11), artinya adalah informasi dalam website UNAIR belum sepenuhnya lengkap karena ada beberapa responden yang tidak mendapatkan informasi yang mereka cari seperti koleksi buku baru perpustakaan UNAIR.

2) Informasi dalam website perpustakaan UNAIR sesuai kebutuhan pengguna termasuk dalam kategori sedang dengan nilai 106 (poin 12), artinya adalah ada beerapa informasi yang dibutuhkan pengguna ternyata tidak ada dalam website walaupun hanya $30 \%$ responden yang menyatakan tidak setuju, maupun ini harus menjadi perhatian bagi pimpinan UNAIR karena website merupakan media promosi bagi sebuah organisasi.

3) Informasi dalam website perpustakaan UNAIR menarik pengguna termasuk dalam kategori sedang dengan nilai 112 (poin 13), sehingga perpustakaan UNAIR perlu menambahkan sentuhan yang atraktif dan menarik di dalam websitenya untuk menambah pengguna website.

4) Informasi dalam website perpsutakaan UNAIR dapat dipercaya oleh pengguna termasuk dalam kategori tinggi dengan nilai 88 (poin 14), artinya bahwa segala macam informasi yang diberikan oleh perpustakaan melalui website, maka pengguna akan percaya dengan informasi tersebut. Dengan demikian diharapkan perpustakaan UNAIR harus dapat menyaring informasi yang akan diunggah ke dalam website karena informassi tersebut akan dipercayai atau d i a ng a p valid ole h penggunanya.

5) Informasi dalam website perpsutakaan UNAIR dapat diidentifikasi dengan jelas oleh pengguna termasuk dalam kategori tinggi dengan nilai 96 (poin 15), artinya tampilan atau navigas website UNAIR sudah memenuhi 
Kaidah usability yaitu user friendly dan mudah dipahami oleh pengguna baik yang baru masuk atau yang sudah lama menggunakan.

6) Informasi dalam website perpustakaan UNAIR dapat terpercaya termasuk dalam kategori tinggi dengan nilai 89 (poin 16), sehingga seperti pada poin 4 diatas maka perpustakaan UNAIR harus memperhatikan informassi yang akan diunggah ke halaman websitenya.

7) Pengguna bisa mengakses informasi dalam website perpustakaan UNAIR secara fultext termasuk dalam kategori sedang dengan nilai 112 (poin 17), artinya adalah di perpustakaan UNAIR masih ada beberapa informasi yag tidak dapat diakses fulltext oleh pengguna. Hal ini merupakan kebijakan dari perpustakaan bahwa informasi dapat diakses secara fulltext hanya dengan menggunakan IP perpustakaan. Kebijakan ini diberlakukan untuk mengurangi tindak plagiarisme.

8) Informasi dalam website perpustakaan UNAIR dapat diakses dimana saja termasuk dalam kategori tinggi dengan nilai 88 (poin $18)$, artinya adalah pengguna dapat mengakses informasi dimana saja, namun sesuai dengan penjelasan point 8 kalau pengguna mengakses di luar IP perpustakaan maka akan ada beberapa informasi yang berisi abstrak saja.

9) Informasi dalam website perpustakaan UNAIR dapat diakses oleh siapa saja termasuk dalam kategori sedang dengan nilai 101 (poin 19), artinya bahwa perpustakaan UNAIR memberikan kebebasan kepada siapa saja untuk mengakses informasinya dan tidak terbatas pada sivitas akademika.

Dari 50 kuisioner yang kami sebar, $85 \%$ dari semua responden menilai bahwa bahasa serta navigasi yang ada di website perpustakaan UNAIR ini sangat mudah di pahami. 70\% dari mereka mengatakan bahwa dapat mempercayai informasi yang terdapat di website perpustakaan UNAIR ini dikarenakan website tersebut merupakan page comersil jadi pastinya informasi yang di update dipilah lebih teliti dengan sumber yang jelas, karena jika tidak ada kejelasan maka mudah saja website tersebut untuk di tuntut atau bisa dikatakan juga sebagai plagiat. Kebanyakan dari mereka sekitar 80\% mengatakan juga bahwa tampilan yang di suguhkan kepada user ini kurang menarik dan untuk pengguna baru biasa jadi menyulitkan, karena tampilannya rumit, sehingga kebanyakan user ini malas lagi untuk mengakses. Responden juga mengatakan kurangnya promosi terhadap user education maupun promosi lain sehingga menjadi kendala untuk 
perluasan atau penyebaran informasi yang ada di website perpustakaan UNAIR, sehingga fungsi dari website ini kurang optimal. Selain itu kritik dari responden antara lain, yaitu : 1) Perlu adanya idak mengganggu aktivitas user dan tidak mengecewakan.

Harapan dari responden, semoga kedepannya website perpustakaan UNAIR menjadi lebih baik, lebih update

Tabel 2.

Hasil User Evaluation secara keseluruhan

\begin{tabular}{|c|c|c|c|c|}
\hline No & Dimensi & Variabel & Nilai & Kategori \\
\hline 1 & Format & kuisoner no 5 s.d 6 & 89.5 & Tinggi \\
\hline 2 & Coverage & kuisoner no 7 s.d 11 & 109.6 & Sedang \\
\hline 3 & Relevance & kuisoner no 12 s.d 13 & 109 & Sedang \\
\hline 4 & Reliable & kuisoner no 14 s.d 16 & 91 & Tinggi \\
\hline 5 & Level & kuisoner no 17 s.d 19 & 100.3 & Sedang \\
\hline \multicolumn{3}{|c|}{ Rata-rata } & 99.9 & Tinggi \\
\hline
\end{tabular}

kemudahan akses apalagi untuk koleksi digital atau elektronik, akan lebih baik jika diadakan upaya jaringan intranet untuk kemudahan akses bagi pengguna sehingga berdampak untuk peningkatan kunjungan dan promosi 2) Lebih banyak lagi koleksi buku yang dapat di akses di website 3) menambahkan informasi lowongan kerja untuk mahasiswa yang baru lulus 4) mempublikasikan contoh buku terbaru yang dimiliki. Untuk hal yang perlu di waspadai yaitu pada saat proses maintenance, karena responden mengatakan bahwa pada saat proses tersebut terkadang mengganggu kegiatan akses mereka, sehingga server sering down. Ini juga dapat mengurangi minat user untuk mengakses, karena pengalaman buruk yang mereka dapatkan dapat berpengaruh untuk kedepannya website tersebut. Jadi waktu maintenance perlu direncanakan lebih baik lagi agar dan lebih menarik pastinya sehingga tidak merumitkan pengguna yang baru karena kesan pertama mereka sangat mempengaruhi juga untuk website perpustakaan UNAIR serta informasi yang diberikan lebih diperluas lagi karena terkadang masih ada informasi yang dibutuhkan user tidak terpenuhi.

Berdasarkan tabel 2 dapat dijelaskan tentang usefulness yang diungkapkan oleh Hugi \& Schneider (2013) terhadap website perpustakaan Universitas Airlangga (lib.unair.ac.id) yaitu:

a) Relevansi (yaitu kesesuaian informasi yang ditemukan sesuai dengan kebutuhannya) masuk dalam kategori sedang, sehingga masih ada beberapa informasi yang tidak ditemukan atau tidak sesuai dengan kebutuhan pengguna di website perpustakaan. 
B) Format (misalnya .pdf, .jpg lain .doc) masuk dalam kategori tinggi, sehingga format yang diberikan website UNAIR sudah memenuhi standart yang sudah ada.

c) Kehandalan (yaitu pentingnya dan kepercayaan diberikan kepada hasil pencarian dalam korespondensi untuk informasi perlu atau diberikan tugas masuk dalam kategori tinggi.

d) Tingkat (seperti meta data, abstrak, teks lengkap dll) masuk dalam kategori sedang, hal ini disebebkan karena kebijakan perpustakaan yaitu fulltext hanya bisa diakses di IP perpustakaan.

e) Cakupan (yaitu ketepatan waktu dalam hal up-to-date atau kelengkapan diakronis) masuk dalam kategori sedang.

\section{Kesimpulan dan Saran}

\section{Kesimpulan}

Dari penelitian diatas dapat disimpulkan bahwa usefullness dari website perpustakaan UNAIR (lib.unair.ac.id) termasuk dalam kategori tinggi dengan nilai 99.9, meskipun masuk dalam kategori tinggi namun perpustakaan perlu memperhatikan banyak hal karena poinnya sangat mudah untuk masuk kategori sedang. Kesimpulan yang kedua adalah yang paling tinggi poinnya adalah format
(Misalnya .pdf, .jpg lain .doc) dengan point 89.5 dan yang paling rendah adalah cakupan (yaitu ketepatan waktu dalam hal up-to-date atau kelengkapan diakronis) dengan nilai 109.6

\section{Saran}

Dari hasil penelitian dapat disarankan beberapa hal yaitu perpustakaan harus lebih memperhatikan tampilan agar lebih menarik pengguna. Kebijakan tentang akses diluar perpustakaan perlu dipertimbangkan lagi karena pengguna saat ini menginginkan layanan yang cepat tepat dan handal. Perpustakaan perlu lebih mengupdate informasi yang diberikan sehingga informasi terbaru cepat tersampaikan.

\section{DAFTAR PUSTAKA}

Bungin, Burhan, 2009, Metodologi Penelitian Kuantitatif: Komunikasi, Ekonomi,dan Kebijakan Publik Serta Ilmu-Ilmu Sosial Lainny. Kencana Media group, Jakarta.

Griffin. 1999. An Architecture for Collaborative Math and Science Digital Libraries, MS thesis Virginia Tech Department of Computer Science, Blacksburg, VA.

Hugi. Jasmin \& Scheider. Rene. 2013. A framework for evaluating the usefulness of digital libraries. In formationswissen s chaft zwischen virtueller Infrastruktur und materiellen Lebenswelten : Information Science between Virtual Infrastructure and Material Lifeworlds : Proceedings des 13. 
Internationalen Symposiums für Informationswissenschaft (ISI 2013), Potsdam, Deutschland, 19. bis 22. März 2013. Glückstadt : W. Hülsbusch, 2013, p. i-xii

Pendit, Putu Laxman. 2008. Perpustakaan Digital dari A sampai Z. Jakarta: Cita Karyakarsa Mandiri.

Sulistyo-Basuki. 1991. Pengantar Ilmu Perpustakaan. Jakarta : Gramedia Pustaka Utama

$\underline{\text { Sumber online : }}$

Horovitz, Bruce. 2012. After Gen X, Millennials, what should next $g$ e ne ration $n$ e ? http://usatoday30.usatoday.com/ money/advertising/story/201205-03/naming-the-nextgeneration $/ 54737518 / 1$

Nielsen, Jacob. 2010. Website Response Times.http://www.nngroup.com/a rticles/website-response-times/.

Peterson, Hayley. 2014, Millennials Are Old News - Here's Everything You Should Know About $\mathrm{G}$ e $\mathrm{n}$ e $\mathrm{r}$ a $\mathrm{t}$ i o $\mathrm{n} \quad \mathrm{Z}$. http://www.businessinsider.co.id/ generation-z-spending-habits0146/?r=US\&IR=T\#.VINKj161XIU

Purtini. Winy, Perpustakaan digital, http://www.indonesiadln.org/wiki /inde x.php/ Main Page

Rufaidah, Vivit Wardah. 2009. Evaluasi Perpusatkaan Digital MelaluiTransaction Log Analysis (TLA). Visi Pustaka, Vol. 11 No. 1 - April 2009. Diakses melalui www.pnri.go.id/MajalahOnlineA dd.aspx?id=115

Surachman, Arif. 2011. Jaringan Perpustakan Digital di Indonesia: Pembelajaran dari Indonesia
DLN, Jogjalib for All, Garuda dan Jogjalib.net. Makalah dalam Konferensi Perpustakaan Digital Indonesia ke-4, Samarinda 8-10 $\mathrm{N}$ o v e m b e $\mathrm{r} \quad 2 \quad 0 \quad 1 \quad 1$. Http://kpdi4.pnri.go.id/Flip_KPD I4/index.html 